\title{
Continuity and change: the culture of ritual and procession in the parliaments of Scotland
}

Dr. Alastair J. Mann (Stirling University)

Ritual is a key part of the parliamentary culture of national assemblies. Sounds, symbols and ceremonial provide continuity and the reassuring presence of traditional values. Both representatives and represented, before and after modern democratic developments, gathered then and gather now to observe the ceremonial proprieties and, in particular, where the indications of sovereignty and legitimacy are shared or transferred as played out in public view. This is seen most clearly in state openings of parliament as expressed within the available space and geography of ritual. But establishing a ritualistic tradition takes time. The vacillation and uncertainty over ceremonial for the new post 1999 Scottish Parliament, in the light of its medieval and early modern precursor, shows how articulating the rules of ritual can be fraught with difficulties. This is highlighted not merely by the first opening in 1999 but also those of 2003 and 2007 greeting the second and third sessions, and also the special opening of the new parliamentary chamber at Holyrood in $2004 .^{1}$

The historiography dealing with the old pre-1707 Scottish Parliament, that is before the parliamentary Union between Scotland and England, has grown in maturity in recent years as source-based studies have overcome the prejudiced accounts of three centuries. ${ }^{2}$ However, both whig and nationalist histories retain a dismissive view of the old Scottish Parliament. Whether the Union delivered Scotland from institutional primitivism or the Act of Union was a dreadful sell-out by a Parliament only recently beginning to be representative and barely worth the saving, the old meeting of the Scottish estates is

\footnotetext{
${ }^{1}$ For early modern Scotland the starting point is the slight historiography of general ceremonial. See for example Douglas Gray's 'The Royal Entry in Sixteenth-century Scotland' in S. Mapstone and J. Wood (eds.), The Rose and the Thistle: Essays on the Culture of Late Medieval and Renaissance Scotland, (East Linton, 1998), pp.10-37 and Michael Lynch's 'Court ceremony and ritual during the personal reign of James VI' in J. Goodare and M. Lynch (eds.), The Reign of James VI, (East Linton, 2000), pp.71-92.

${ }^{2}$ For example J. Goodare, 'The Scottish Parliament of 1621' in The Historical Journal, 38, 1 (1995), pp. 29-51 and 'The Estates in the Scottish Parliament, 1286-1707' in C. Jones (ed.) The Scots and Parliament: Parliamentary History, (Edinburgh, 1996) pp.11-32 and numerous other articles; J.R.Young, The Scottish Parliament 1639-1661: a political and constitutional analysis, (Edinburgh, 1996) and many other articles; R.J. Tanner, The Late Medieval Scottish Parliament, (East Linton, 2001); A. R. MacDonald, 'Deliberative processes in the Scottish parliament before 1639: multi-cameralism and the Lords of the Articles', Scottish Historical Review [hereafter SHR], (2002), pp.23-51 and The Burghs and Parliament in Scotland, c.15501651 (Aldershot, 2007) and A.J. Mann, 'Inglorious revolution: administrative muddle and constitutional change in the Scottish Parliament of William and Mary' in Parliamentary History, 22, part 2 (2003), pp.121-44. R S. Rait's, The Parliaments of Scotland (Glasgow, 1924) still remains, for all its faults, a most informed and wide-ranging parliamentary history but out of the Scottish Parliament Project at St Andrews University see, K.M. Brown and R.J. Tanner (eds.), Parliament and Politics in Scotland, 1286-1567, (Edinburgh, 2004); K. M. Brown and A. J. Mann (eds.), Parliament and Politics in Scotland, 1567-1707, (Edinburgh, 2005) and the forthcoming K. M. Brown and A. R. MacDonald (eds.), The Scottish Parliament: a constitutional history, (Edinburgh, 2010). See also recent political studies such as G. H. MacIntosh, The Scottish Parliament under Charles II, 1660-1685 (Edinburgh, 2007)
} 
rarely cast in a favourable light. ${ }^{3}$ Even stranger are the whig and nationalist strains, odd bedfellows indeed, that celebrate the Parliament as a representative institution but only since the Revolution of 1688-9. ${ }^{4}$ However, such narrow vistas, which have until the last decade dissuaded much investigation, are not especially conducive to comparative history over centuries and to the study of the history of ritual and state openings in the setting of Scottish parliaments past and present. ${ }^{5}$ Scotland's state openings were not of course like revolutions and occurred regardless of political effectiveness and 'colour', but they were vital ingredients of political culture nonetheless.

The pre-1707 Scottish Parliament was, like the parliament of Naples or the states general of France before 1560, a unicameral or single chamber affair. It was also a meeting of three or four estates: the appointed clergy, the first estate, who had an 'in-and-out' history before being finally removed in 1690; the nobility, the second estate, who attended by right; the elected shire members who developed out of the lesser landed nobility and who attended from the 1580s, and the elected burgh members, the third estate, who from the fourteenth century became regular attendees as pressure increased on the crown to raise revenue which required the consent of the merchant community. The elected members, or commissioners as they were known, were chosen by a small electorate still tiny by 1707 , consisting of the lesser landed who elected shire commissioners and individual town councils the burgh commissioners. In spite of the limited franchise, by the late seventeenth century electioneering and party management had become a feature in a way mirroring the House of Commons in England. However, the unicameral nature of the Scottish Parliament ensured it developed on different lines to that of England. As a court of first instance and appeal and a mixture of estates it had some similarities to the House of Lords. Also, the fact that all estates met in a single assembly provided a national representative focus that cannot be discounted when considering the significance of parliamentary ritual. ${ }^{6}$

By the end of the seventeenth century the Scottish Parliament had grown to a gathering of estates of over 200 strong. Each member had a single vote but that did not indicate equality of status. Any ceremonial within the chamber or state opening had to cater not only for an expanding number of members but their respective status and the estate they

\footnotetext{
${ }^{3}$ See Rait, The Parliaments of Scotland; P.W J. Riley, King William and the Scottish Politicians (Edinburgh, 1979) and The Union of England and Scotland (Manchester, 1978); K. Webb, The Growth of Nationalism in Scotland (Harmondsworth, 1978); C. Harvie, Scotland and Nationalism: Scottish Society and Politics, 1707 to the Present (Abingdon, 2004) and P. H. Scott, The Union of 1707: why and how (Edinburgh, 2006)

${ }^{4}$ Harvie, Scotland and Nationalism, pp.15-16.

${ }^{5}$ For detailed reflections on parliament and ritual but without comment on post-1999 developments see A.J.Mann, 'The Scottish Parliaments: the role of ritual and procession in the pre-1707 parliament and the new parliament of 1999' in E.Crewe and M.G.Müller (eds), Rituals in Parliaments: Political, Anthropological and Historical Perspectives on Europe and the United States (Frankfurt am Main, 2006), pp.135-58. See also T. Innes, 'The Scottish Parliament; its symbolism and its ceremonial in Juridical Review, xliv. 2 (1932), pp.87-124 though it contains some fanciful notions.

${ }^{6}$ For European comparisons and a general summary see Brown and Mann (eds.), Parliament and Politics in Scotland, 1567-1707, pp.1-56 and J.R. Young, 'The Scottish Parliament in the Seventeenth Century: European Perspectives' in A.A. Macinnes, T. Riis and F.G. Pederson (eds), Ships, Guns and Bibles in the North Sea and the Baltic States, c.1350-c.1700 (East Linton, 2000), pp.139-72.
} 
represented. Furthermore, ceremonial had to accommodate a crucial change in the practicalities of the Parliament. Although James VI had been an enthusiastic attendee for meetings of the estates, once he succeeded to the English throne in 1603 he returned for only one parliament, that of 1617. Subsequently, Charles I and II came north for only a handful of sessions, and of these only Charles I's coronation visit of 1633 saw the monarch a willingly participant. In the last century of the Scottish Parliament the frequent absence of the king ensured that a royal or High Commissioner was appointed to represent crown authority. This High Commissioner sat on the throne within the chamber as James, duke of York and Albany did for his brother Charles II in 1681.

By the middle of the seventeenth century this raised throne looked down on a large Parliament House built in the 1630s. ${ }^{8}$ The great space that this provided, measuring roughly 40 metres by 13 , was ideal to formalise the stratified nature of the membership. We have no evidence, however, that the regular ceremonial from the 1630s was a significant departure from internal arrangement for other previous venues, such as the West end of St Giles Cathedral, the most common venue in the adult reign of James VI and I, the New Tolbooth to the South West of St Giles, or Edinburgh's Old Tolbooth (town hall) before then. We can only assume that when Parliament was more peripatetic, either for royal convenience in the late medical period or during crisis, as when it met in St Andrews in the winter of 1645-6 when the plague visited itself on Edinburgh, similar elements of internal ritual and physical layout were played out.

Within the old parliamentary chamber members sat in the their various estates in a horseshoe style facing the throne on which the King or his Commissioner sat. Noble and clerical members sat left and right and burgh and shire members faced the throne. In the middle, were three tables: at the one nearest the throne the honours or regalia of Scotland were placed, the crown, sceptre and sword of state, the key symbols of royal power, shared sovereignty and high ceremonial. At the other two tables sat the clerks of parliament, headed by the Clerk Register, and the judges of the Court of Session who, though unable to vote, attended to provide legal advice. ${ }^{9}$ The less confrontational chamber layout and non-party seating arrangements must have helped reduce some heated moments, though such generalisations should be treated with caution. The frequency of heated debates in the semi-circular arrangement of the post-1999 chamber shows a non-confrontational layout less effective in practise.

For the pre-Union Parliament the honours of Scotland were central to the ceremonial before a select audience within the chamber and also, as we shall see, outside to the wider public. The sceptre, in particular, had a crucial role to play in internal procedure. Royal assent was conveyed by the monarch touching the sceptre to a copy of an act, a procedure carried out by the High Commissioner after 1603. In the new Parliament the signature of the monarch confirms assent mirroring the Westminster model and whereas this might be

\footnotetext{
${ }^{7}$ During the seventeenth century the title shifted between 'king's', 'royal' and 'high' Commissioner. See Brown and Mann (eds.), Parliament and Politics in Scotland, 1567-1707, p.28

${ }^{8}$ For an account of the building of the purpose built Hall see Aonghus MacKechnie 'The Crisis of Kingship: 1603-1707', in M. Glendinning (ed.) The Architecture of Scottish Government: from kingship to parliamentary democracy (Dundee, 2004), pp.82-134

${ }^{9}$ Mann, 'Ritual and procession in the Scottish parliament', p.152
} 
seen as a sensible duplication of Westminster procedures it is also indicative of the strange and sometimes awkward convergence of the old and new that characterises modern methodology. But before 1707 the sceptre was the focus of political and constitutional theorising about where sovereignty lay: with monarch or with parliament. In James VI's opinion, no law could pass 'without his scepter put to it for giving force of law', and this made it clear where sovereignty lay. Meanwhile George Buchanan (150682 ), the great Scottish political theorist, argued that sovereignty rests with the estates in parliament not the crown, and the passing on the sceptre and other honours of Scotland during the coronation ceremony created a contractual relationship which conveyed a conditional sovereignty. ${ }^{10}$ Within the old legislative assembly, however, sovereignty was a practical question, ritual being required to show an act had been formally passed, but also to signal consent given by the people's representatives. This was of practical significance as it expressed the widest possible public acquiescence to statutory measures. The 'crown in parliament', a term often used in British constitutional history, reflects these interconnected sovereignties of crown and estates as did the opening preamble used for laws passed in the old Scottish Parliament: 'our sovereign lord, with advice and consent of the estates of parliament, statutes and enacts ...'. The casual frequency with which this legend was used seems in inverse proportion to its undoubted significance.

The other ceremonial elements within the chamber on a state opening were low-key and functional. After the reading of the king's letter to parliament, speeches were given by the High Commissioner and the president of parliament, generally the Chancellor. The rolls were called in due order, prayers were said and a psalm sung by the whole house. Compared to this, the events within the chamber in 1999 and 2004 were extremely lively though not necessarily so spectacular. The fine robes worn by the various parliamentary estates before 1707 had more in common with the attire of members of the House of Lords at modern state openings. However, although in 1999 male members were, according to the fashion writer John Davidson, dressed merely like 'guests at any smart wedding', the tunics of heralds and pursuivants and the kilted attire of the duke of Hamilton as he brought in the crown added colour. In 1999 and 2007 this crown was placed in the middle of the chamber, on a table before the monarch. This reproduction of the procedure of the old now appears a fixed aspect for the new Parliament. Following the entrance of the crown the Queen enters to a fanfare, and then sits in the middle of the chamber amongst the members [MSPs], in a manner that captures the informal involvement of the monarch in the day-to-day activities of the old Parliament. Facilitated by the unicameral nature of the old Parliament, the king or queen joined the debate. And so, appropriately, Queen Elizabeth sits amongst the members of the new unicameral house as she did in 1999, 2003 and 2007. ${ }^{11}$

\footnotetext{
${ }^{10}$ For the debate over sovereignty see A. J. Mann, 'Parliaments, Princes and Presses: Voices of tradition and protest in early modern Scotland', in U. Böker and J.A. Hibbard (eds.), Sites of Discourse: Public and Private Spheres - Legal Culture, (Amsterdam, 2002), pp.79-91 and Mann, 'Ritual and procession in the Scottish parliament', pp.153-4.

${ }^{11}$ Details for 1999 are taken from The Herald, 2 July, 1999, pp.19-22; The Scotsman, 2 July, 1999, special section pp.i-viii and BBC (Scotland) live television broadcast, 1 July, 1999, editor Atholl Duncan. For 2003 see BBC (Scotland) live television broadcast, 3 June, 2003 and Scottish Parliament News Release 035/2003, 1 June, 2003 . For 2007 see BBC (Scotland) live television broadcast, 30 June, 2007 and also at
} 
The processing of the crown into the chamber carried by the 15th duke of Hamilton, which occurred in 1999, 2004 and 2007, certainly reflects the traditions of the old parliament. The duke as earl of Angus and head of the Douglases is hereditary bearer of the crown, and was like his ancestors entrusted with the task of escorting the crown to the Parliament. However, when convoluted discussions were taking place during 1998-9 between Buckingham Place and the Opening Ceremony Working Group set up by the Scottish Office in September 1998, the royal family suggested a less formal arrangement for 1999. In the wake of the death of Princess Diana in 1997, and subsequent efforts by the royal family to establish more informality in official business to counter criticism of aloofness, it was suggested by palace officials that the crown be carried into the chamber by a child.. This was, however, rejected by members of the Working Group as being a modernisation too far, and perhaps too out of step with important Scottish parliamentary traditions. ${ }^{12}$ Two of Scotland's most experienced, commercial events organisers, Unique Events Ltd and UZ Ltd, were appointed in February 1999 to co-ordinate arrangements for the opening ceremony but their view of such populism is unknown. The palace suggestion was reported by the journalist Ruth Wishart in The Herald (2 July) and hinted at during the BBC live broadcast. The decision does not, however, appear in the available minutes of the Working Group. ${ }^{13}$

The Queen's attendance at the state opening of the Scottish Parliament, in 1999 or thereafter, has a single, main purpose: as Queen of Scots to declare the parliament open. Yet in 1999 there was a secondary reason: to present a new symbol of the power and the relationship between parliament and crown, the Mace. Although there is sometimes confusion over this, there was in fact no parliamentary mace before 1707, even though some officers of state, such as the Treasurer, had their own. Therefore, the new 1999 mace, clearly following the style of the House of Commons, is now present at all sittings of the new Parliament. Essentially it can be seen to represent the tensions evident in the relationship with the Westminster model: a mace can, after all, be removed. The words 'Wisdom, Justice, Compassion and Integrity' are cut into the head of the Mace. These may represent the aspirations of the Scottish people but no more than did symbols that adorned the old Parliament House from the 1630s. As the members approached the entrance they were greeted by two statues above the door: on the right Mercy holding a crown wreathed with laurel leaves, and on the left Justice with a balance on one hand and a palm in the other. Underneath was the Latin motto: stant his felicia regna, kingdoms

\footnotetext{
the Scottish Parliament website at http://www.holyrood.tv/library.asp?title=Session\%203\%20Event\%20Archive\&section=99 $($ accessed 20 April, 2009)

${ }^{12}$ The Opening Ceremony Working Group was a diverse body including Scottish Office staff, representatives of Buckingham Palace, The Lord Lyon King of Arms, Lothian and Borders Police, the armed services, the city of Edinburgh and representatives of Historic Scotland, a public agency responsible to Scottish Ministers for safeguarding the nation's built heritage.

${ }^{13}$ Scottish Parliament News Release 0207/99, 2 February, 1999; The Herald, 2 July, 1999
} 
stand happy by these virtues. Early modern society also had aspirations for good governance. ${ }^{14}$

After the Queen completed her opening speech in 1999, the subsequent involvement of non-members was a departure from 1703. As we have seen, in the old Parliament members of the Court of Session were allowed to sit in the chamber to provide legal advice, and they and other experts like army officers and merchants were called upon to advise but they could not vote and were not part of the internal ceremonial ensemble. Yet music and verse came together in 1999 in a manner that reflected a wider participation. A poem was read from the gallery, a song by Robert Burns was sung by the entire gathering, and, following on from the First Minister's speech, a poem written by a school girl was read out to the assembly. Lastly, as in the old Parliament, a psalm was sung before queen and crown left the stage. In 2004, when the Queen participated in celebrations commemorating the opening of the new Holyrood building, the opening ceremony included a performance from the young Scottish violinist Nicola Benedetti, a reading by Liz Lockhead of a specially commissioned poem called 'Come on in' by Scotland's poet laureate Edwin Morgan, and finally a performance by the singersongwriter Eddi Reader who led the chamber and monarch in the singing of Robert Burn's 'Auld Lang Syne'. ${ }^{15}$ However, in 2007 almost all internal musical and celebratory highlights ceased and the only musical elements were the fanfares when the crown and queen entered and departed the chamber. Celebrating great events like a new parliament or a new chamber was one thing, but merely marking a new input of members of parliament in 2007 saw sobriety replace rejoicing, other than the restrained humour of the speeches of the Presiding Officer Alex Ferguson and of the Queen herself.

Nevertheless, the pride of place given to the crown is perhaps the most significant gesture to symbolic traditionalism in both 2007 and 1999. Before 1707, however, all three honours of state were present. These consisted of the sceptre, the sword of state and lastly the crown, all of which survive today, thanks in part to the trusteeship of Sir Walter Scott who persuaded The Prince Regent (later George IV) to permit the rediscovery of them in Edinburgh Castle and to give them the rightful attention of conservation and tourism. The sceptre was, in the words of the Scottish coronation ceremony: 'the sign of royal power, the rod of the kingdom, the rod of virtue, [to] govern ... aright ... punish the wicked and protect the just'. ${ }^{16}$ This silver gilt wand, with a globe of crystal and a Scottish pearl, is the oldest of the honours and was presented by Pope Alexander VI to James IV in 1494 and, as we have seen, played a crucial role in conveying royal assent. In fact, after the Union

\footnotetext{
${ }^{14}$ Mackechnie, 'Crisis of Kingship', pp.112-3. For other details of Parliament Hall see Royal Commission for the Ancient Monuments of Scotland: the City of Edinburgh (HMSO, Edinburgh, 1951), pp.90-92 and R.K. Hannay's description in The Book of the Old Edinburgh Club, vol.13 (Edinburgh, 1924), pp.1-78.

${ }^{15}$ For 2004 details see BBC (Scotland) live television broadcast, 9 October, 2004 (no editor); Scottish Parliament Annual Report at http://www.scottish.parliament.uk/corporate/anrep-accts/spar/ar05/ceremony.htm (acccessed 1 May, 2009)

${ }^{16}$ For quote (taken from 1633 coronation) see F. Grant, 'State Ceremonials in Edinburgh in the Olden Time' in The Book of the Old Edinburgh Club, vol.18 (Edinburgh, 1932), p.21. A useful clear description of the honours of Scotland can be found in Brain Barker, The Symbols of Sovereignty, (Newton Abbot, 1979), pp.216-31.
} 
of the Crowns in 1603 there were logistical difficulties associated with arrangements for the crown substitute, the High Commissioner. Commissioners had to be adequately instructed in London as to what was allowable before the session commenced in Edinburgh, and sometimes members opposed to court policy used the hesitancy of royal assent to criticise the competence of government ministers, as seen in the political difficulties faced by the duke of Lauderdale, Commissioner in the 1670 s, or by ministers operating in the final Anglo-Scottish, pre-Union political crisis from 1703 to $1706 .{ }^{17}$ The sceptre being wielded by a crown servant rather than the king helped encourage the development of party politics in the second half of the seventeenth century.

The second oldest honour, the silver sword of state, the symbol of warrior strength, and of the protection of liberty, territory and of faith, was presented to James IV by Pope Julius II in 1507, while the youngest honour, the crown, the symbol of coronation investiture, of unity and of empire, was in fact made of ancient stones re-crafted about 1540 in the reign of James V. This crown first appeared, along with the other two honours, for the coronation of the baby Mary, Queen of Scots in 1543. But even before this time the honours were important as actual and mythical embodiments of independence from England from the thirteenth century and the Anglo-Scots Wars of Independence to the eventual Union of 1707. Even as the Union negotiations were taking place in 1706/7, the Scottish Parliament required re-assurances on the fate of the honours of Scotland along with the official records of parliament: they were not allowed to leave Scotland and the honours were locked in a secure chest and stored in Edinburgh Castle. As the $24^{\text {th }}$ Article of the Treaty of Union states:

hereafter ... the crown, scepter and sword of state, the records of parliament, and all other records, rolls and registers whatsoever, both publick and private, general and particular, and warrands thereof, continue to be keeped as they are within that part of the United Kingdom now called Scotland, and that they shall so remain, in all times coming, notwithstanding the union. ${ }^{18}$

The significance placed on these national symbols was unchanged by the revolutions of the sixteenth and seventeenth centuries. Although the sword is adorned with the emblems of the papacy and the figures of St Peter and St Paul, and the sceptre has at its head the three figures of St. James, St. Andrew and the Virgin Mary, the essential nature of the honours was not affected by Scotland's Protestant Reformation in 1560, and the subsequent anti-Catholic political culture. The belief was simply that no session of parliament was legitimate without the presence of the honours. The pride with which the Scottish revolutionary Covenanters seized the honours and marched them back to Edinburgh Castle, along with their insistence that the honours were displayed at all gatherings of the estates, confirms the link they had to legitimate representation. After

\footnotetext{
17 For the 1703 to 1706 crisis see Nation Archives of Scotland [NAS], Hamilton Muniments, GD 406/1/5153 (Letter by James Douglas, 6th duke of Hamilton, dated 10 September, 1703) and for the complexities of commissioners' instructions and subsequent difficulties see Mann, 'Inglorious revolution: administrative muddle and constitutional change in the Scottish Parliament of William and Mary', pp.13440.

${ }^{18}$ K.M. Brown et al (eds), The Records of the Paliaments of Scotland to 1707 [RPS] (St Andrews, 2009) at http://www.rps.ac.uk RPS, 1706/10/363
} 
1603, when the king was absent, the honours were always there to signify crown acceptance of the power of Parliament. ${ }^{19}$

The most ostentatious and public ceremonial of the state openings of both the old and new Scottish parliaments was and is the 'riding of parliament'. For the old Parliament this was a largely equestrian procession from royal palace to parliamentary chamber, and is a specifically Scottish ceremony. ${ }^{20}$ It dates back at least to the 1520 s, although the first detailed mention in the parliamentary record occurred in 1587 when absentees from the ceremony were to be fined. Essentially, wherever Parliament met, mostly in Edinburgh from the 1460s and the reign of James III, or at venues such as Perth, Linlithgow or especially Stirling, a short journey was required from the royal palace or castle to the place where the estates assembled. This journey represented the movement from a royal and fortified environment to neutral ground where the estates could gather without fear of coercion. This safe environment for the estates to gather was seen as a fundamental right by some parliamentarians. In 1578 the Parliament convened at Stirling Castle was viewed by some nobles and burgh members as unsafe on account that it was summoned to a fortified place. The burgh commissioners met in Stirling Tolbooth and would not gather in the Castle until the boy King James VI and his regent the earl of Morton gave assurances that Parlament would meet freely and without molestation. ${ }^{21}$ Eventually in the 1630s the desire for a neutral venue was satisfied by a purpose-built Parliament House erected in Edinburgh, but these fears of coercion in part account for the medieval and early modern estates meeting in various churches and burgh tolbooths and not always in royal palaces or castles.

The ceremonial 'riding' occurred at the beginning (down-sitting) and end (rising) of each parliament, but not for every session. A dissolution of Parliament was needed before a concluding 'riding' and therefore also before a state opening was required for the next session. The succession of a new monarch, however, led both to a new general election and a 'riding' thereafter, and the fact that with the modern Parliament a 'riding' follows a general election is entirely appropriate. However, in the last two decades of the old Parliament's history usual procedures were suspended. The parliament formed after the election to the revolutionary estates in 1689, which was transformed into a full parliament by agreement with King William and Queen Mary, not only had no 'riding' but was not followed by a general election before King William died in 1702. The 1703 'riding', at the beginning of the reign of Queen Anne, was to be the last in the Parliament's history, and no attempt was made to hold a concluding 'riding' to mark the final adjournment in

\footnotetext{
${ }^{19}$ The symbolism suggested by the honours has been informed by the following: J. Chevalier and A. Gheerbrant, A Dictionary of Symbols, (trans. John Buchanan-Brown), (Oxford, 1994), pp.834 and 959-60 and A. de Vries, A Dictionary of Symbols and Imagery, (Amsterdam/London, 1974), pp.308; 403-4; 452-4.

${ }^{20}$ For the slim historiography of the 'riding' see 'The method and manner of Ryding the Scottish Parliament' in Maitland Club Miscellany, iii, pt 1. (Edinburgh, 1842), pp.101-37, which lists Privy Council regulation; C. S. Terry, The Scottish Parliament: its constitution and procedure, 1603-1707, (Glasgow, 1905), pp.94-102; and Rait, Parliaments of Scotland, pp.529-34. A brief if impressionistic mention is found in Grant, 'State Ceremonials in Edinburgh in the Olden Time', pp.11-32.

${ }^{21}$ David Calderwood, A History of the Kirk of Scotland, ed. T. Thomson (8 vols), (Wodrow Society, Edinburgh, 1842 (first published 1678)), iii, pp.413-14; David Moysie, Memoirs of the Affairs of Scotland, 1577-1603, ed. J. Dennistoun, (Bannatyne Club, Edinburgh, 1830), pp.8-9 and NAS. PA2/12, f.1r
} 
1707 for fear of encouraging popular protest against the parliamentary Union. The last months of the Union negotiations had already witnessed popular disaffection with the process and even the targeted threat of violence against some pro-Union members of parliament.

The 'riding' ceremony in 1703 began with the assembly of members of parliament and officials in the square before the palace of Holyrood and the transportation of the honours of Scotland from Edinburgh Castle to the palace. The order of procession from palace to Parliament House then followed with most senior last, a procedure that ensured that all were gathered to witness the arrival of the monarch, or in his absence the Commissioner accompanied by the honours of state. Precedency indeed followed that in the parliamentary role used for voting. However, this was not an easy rule to apply and there were regular disputes which were resolved by the Clerk Register, the senior clerk of parliament, in consultation with the Lyon King at Arms, the judge in all matters of heraldry and seniority, and the individual who had overall responsibility for managing the 'riding'. In 1681, after disputes were resolved and the order confirmed, the members proceeded up the High Street on horseback two by two led by trumpeters and pursuivants (officers of the Lyon Court who still feature in the new Parliament's state opening); then the Lord Chancellor (the president of the parliament), burgh members followed by the shire members; then the lords, bishops (before 1689), viscounts, and earls; archbishops (also before 1689); more trumpeters, pursuivants and heralds; then the honours of Scotland, borne by three of the most senior nobles ranked by macers for protection; followed by the High Commissioner (from 1603); the dukes and marquises, and lastly the captain of the royal guard with his troop. If the monarch was present, which he was in $1617,1633,1641$ and 1651, then the marquises and dukes rode after the earls, with the monarch following last with his royal guard. ${ }^{22}$

Although this gives the impression of a couple of hundred members, the total involved in the 'riding' was swollen by fixed numbers of servants and retainers on foot. Restrictions were placed on retinue according to status. In 1703 this was set as follows: 'Every duke is to have eight lackies, every marquess six, every earl four, every viscount three, every lord three, every commissioner for a shire two, and every commissioner from burghs one'. ${ }^{23}$ With over 200 horses, a 1,000 or so moved by procession to the Parliament Close by St. Giles Cathedral and then, after dismounting at a dismounting area to the East end of St Giles, equivalent to the mounting area made ready at Holyrood, all walked to the Parliament House. It must have been a riotous scene of colour and noise and, with all the horses, one of complete chaos in the narrow High Street around St Giles. We know that on occasions horses bolted and some members failed to reach the Parliament House. Such a fate befell John Gordon, Viscount Kenmuir in $1669 .{ }^{24}$

\footnotetext{
${ }^{22}$ There are various versions of this order, but that of 1681 is typical. See Registers of the Privy Council (Scotland) [RPC], 3rd series, vii, pp.169-70 and Maitland Club Miscellany, pp.119-23. Rait, Parliaments of Scotland, p.532. Records survive for 1612, 1633, 1669, 1681 and 1703. See Mann, 'Ritual and procession in the Scottish parliament', pp.142-44.

${ }^{23}$ RPS, A1703/5/1 (6 May, 1703)

${ }^{24}$ NAS, Duke of Buccleuch Papers, GD 224/605/1.
} 
To match the processional sequence there was also a dress code by status and estate. This developed from the 1450s with different codes set for earls, lords, burgh and shire members. At least controversies surrounding clerical attire, a feature of Scottish political and religious life from 1560, were removed when the clergy were withdrawn from Parliament in 1689. Yet horse livery also became a feature in the seventeenth century as velvet foot-mantles were added for even burgh members. ${ }^{25}$ By 1703 the sartorial magnificence must have been striking: nobles in scarlet robes, with elaborate horse footmantles and extra servants carrying the train of their robes; foot-mantles also for all pursuivants, heralds and macers; velvet coats and livery for the servants of nobles and retainers; and officers of state carrying before them the symbols of office, the Great Seal in a velvet pouch before the Chancellor and a silver mace before the Treasurer. ${ }^{26}$ In the modern age it is not so easy to carry out such ceremonial duties. Irresolution regarding the correct procedure in the new Parliament is seen in the First Minister Jack McConnell acting out the role of official purse bearer and awkwardly carrying a velvet pouch in 2003. This had been since 1603 a traditional role for the Keeper of the Great Seal of Scotland, a position held by the First Minister from 1999. But media stupefaction at the comical sight in 2002 during the Queen's jubilee tour, and in the 2003 state opening, were intensified when it was realised that the pouch is always empty, the Great Seal being too valuable to carry about. This was not a procedure repeated publicly by McConnell's successor Alex Salmond in 2007! $!^{27}$ Yet in 1703 there were no such uncertainties - indeed, this first parliament of the reign was a ceremonial highpoint as were the first parliaments of Charles I and James VII and II in 1633 and 1685. The 1703 opening under Queen Anne, following what was the last general election of the old Parliament's history, was perhaps one of the greatest processional events of early modern Scotland.

As for the modern Parliament, the 'riding' for the first state opening in July 1999 was also more magnificent than those that greeted the second and third sessions of parliament in 2003 and 2007. The opening and 'riding' was one of the largest Scottish news events of modern times. Many thousands gathered on Edinburgh's High Street to watch the procession from the royal palace of Holyrood to the temporary home of the Parliament, the Assembly Hall of the Church of Scotland. To quote the Glasgow Herald newspaper, a pro-devolution broadsheet: 'The excitement among the crowd [held back by barriers, police and soldiers] was almost tangible with the imminent approach of the Queen's carriage, flanked by the Household Cavalry. ...And [when] the royal party arrived ...onlookers ... let out a roar and raised high their flags as overhead, people watched from windows'. ${ }^{28}$ What a contrast between optmistic celebratory ritual and the cut and thrust of practical politics. In external spectacle the pre-1707 Parliament was no different, of course. In 1669 the procession to the opening of Parliament, again departing from Holyrood but then arriving at the old Parliament House near St. Giles Cathedral, saw 'the

\footnotetext{
${ }^{25}$ For the various changes in dress code agreed by Parliament see RPS, 1430/12-14; 1455/8/12; 1587/7/26 and 1661/1/316. For Privy Council regulation: RPC, 1 st series vii, pp.57-8; 488-9 and 208-9; RPC, 1 st series viii, pp.233-4. For a summary see Terry, Scottish Parliament, pp.97-100.

${ }^{26}$ Maitland Club Miscellany, pp.131-35.

${ }^{27}$ For an example of media mockery see Joyce McMillan in The Scotsman, 28 May, 2002.

${ }^{28}$ The Herald, 2 July, 1999, p.22
} 
whole [high] street .. lined with townsmen', held back by the troops. Rugs and carpets were hung from the windows of the buildings, and women and children watched from the upper floors. ${ }^{29}$ Order was also a concern for the authorities. In 1703 the Scottish Privy Council outlawed the throwing of fireworks, shooting, and the beating of drums that might scare the horses, ${ }^{30}$ but that could hardly prevent shouts of protest as unpopular High Commissioners, such as the duke of Lauderdale (1678) or the duke of Albany and York (1681), made their way to Parliament. ${ }^{31}$ In 1999, with soldiers and police lining the route, four students protesting at the introduction of tuition fees vaulted the barriers and approached the royal coach before being arrested.

The 1999 procession was not too unlike that of 1703 in that it was carried out with a similar axis of ritual - castle and palace at the extremes and the chamber occupying a central position. The 'journey' to the parliament's temporary home the Assembly Hall of the Church of Scotland was a three part process. Firstly, the crown, the only honour to feature, was transported from Edinburgh Castle to the chamber. The duke of Hamilton escorted the crown to the Parliament under armed guard, in a traditional procedure found in 1703. Simultaeously, the MSPs and other VIPs, gathered in the old Parliament Hall near St. Giles, now a lobby to the Court of Session, the highest civil court of Scotland. After various speeches reflecting on the old Parliament they made a brief informal walk to the chamber flanked by children representing the regions of Scotland. Then the third stage, the 'traditional' journey of monarch from palace to parliament, took place although in a Westminster manner the Queen travelled in an open state coach guarded by a squadron of lifeguards. At the start of the brief 10 minute royal journey from Holyrood Palace trumpets sounded and the British national anthem was played, the only occasion it was played that day. During the subsequent small procession of 30 horses and a single coach, a twenty-one gun salute was fired from the Castle. Such canons were also employed in the old 'riding' to confirm the arrival of monarch and/or the honours. ${ }^{32}$

When in 1999 the queen and the crown left the chamber after the internal ceremonials we see a departure from the pre-1707 conventions. Instead of processing back to Holyrood the Queen sat at a dais with the First Minister and watched a procession of children and residents representing the regions of Scotland. The children carried banners - Himalayan prayer flags designed by a Buddhist monastery in Dumfries and represented eight different facets of Scottish life, economic, social and cultural. This multi-culturalism was and is also reflected in the ecumenical service the 'kirking of parliament' which takes place in a service in St. Giles the evening before. But equally secularism is suggested by the weak significance placed on religion within and without of the chamber itself. The state opening is now markedly without religion, other than the singing of a single psalm in 1999 which was completely abandoned in 2007. The emphasis on Scotland's place in the secular and multi-faith modern world contrasts with the early modern Christian conscience that thanked 'Almighty God'.

\footnotetext{
${ }^{29}$ NAS, Duke of Buccleuch Papers, GD 224/605/1.

${ }^{30}$ NAS, Acta of Privy Council [APC], 29 April 1703; APC, 5 May, 1703.

31 The duke of Albany was popular with the political classes in 1681 but his known Catholicism was distrusted in wider society.

${ }^{32}$ Maitland Club Miscellany, p.118, ex. 'Order and Progres of the Parlement October 1612'
} 
But contrasts cannot just be made between 1703 and 1999. The rituals and processions since 1999 have not only varied in structure but have also shown the uncertainties associated with ceremonial in a Scottish and British context. The 2003 opening was a downplayed affair as the Parliament was embarrassed at not having completed the new building on time and on budget. The Presiding Officer Sir David Steel had to re-assure both media and MSPs that the Scottish Parliament Corporate Body, the multi-party committee responsible for managing the budget for the new parliament, had spent none of the $£ 400,000$ budget set aside for the eventual grand opening. The Scotsman newspaper reported in November 2002, under the heading 'Holyrood opening ceremony shelved' that it was the opening of the new building in 2004 that would be the downplayed event, but in fact both 2003 and 2004 ceremonies were affected to a degree. ${ }^{33}$ At least in 2003, like 1999, the Queen's journey from palace (Holyrood) to chamber (the Assembly Hall of the Church of Scotland on The Mound) retained the same spatial geography, though she travelled by car not coach. But the ceremony in 2003 was extremely brief and devoid of spectacle, and owed more to the extraordinary meeting of the Parliament in Aberdeen in May 2002 when the Queen addressed the chamber.

In the week commencing 27 May 2002 the Scottish Parliament had to vacate the Assembly Hall in Edinburgh for a week while the General Assembly of the Church of Scotland has its annual meeting. It being the year of the Queen's jubilee her address to the minsters and elders of the Kirk required them to resume their residency of the Assembly on The Mound. Meanwhile, Aberdeen University's King's College Conference Centre complex provided an alterative home for the Parliament that week, and the Queen, again as part of her jubilee tour, took the opportunity to address a standard session of the house, the first time this has occurred in the new Parliament. ${ }^{34}$ For this brief ceremony of a few speeches, apart from the fanfare greeting the Queen on entering the chamber, there was very little formality. This was patently not a state opening. However, in the following year the state opening back at the Assembly Hall in Edinburgh was also remarkably brief and lacking in ritual. There was no 'riding' of parliament; no 'crown' present, only the Mace to represent crown authority; no formal procession, other than the trumpet fanfare as the Queen and the Mace entered and departed. The whole process took under 25 minutes to complete. The only musical event was the singing of a Gaelic choir located in the quadrangle at the entrance to the hall and the Queen's last duty as she departed was to meet with some of the choir and a selected group of school children. Overall the political embarrassment of having no new building for the state opening of 2003, heightened as it was by an outraged Scottish and British press, weakened the resolve of MSPs and left them hesitant in the execution and budgeting of ceremonial.

When the state opening of 30 June 2007 occurred, after the election the previous May in which the Scottish National Party formed their first, though minority administration, the details of ceremonial occurred in the light of the special opening of the new parliamentary chamber in 2004. The 2004 event, on Saturday 9 October, introduced the

\footnotetext{
${ }^{33}$ The Scotman, 27 November, 2002.

${ }^{34}$ For detials of the 2002 event see BBC (Scotland) 'Holyrood Live Special', 28 May, 2002.
} 
new cramped spatial geography with which all ritual must contend in the future. ${ }^{35}$ Proceedings began with the MSPs, judges, clergy, military officers and VIPs, along with members of the public chosen by a ballot from every region of Scotland, gathering in the old Parliament Hall behind St Giles Cathedral at which speeches were made before the Queen. After this the Queen proceeded to a dais located outside the City Chambers just down the Royal Mile to watch a 'riding' procession move from St Giles down to the Holyrood Parliament building. As well as party leaders and presiding officers, this walking procession consisted of over 1,000 guest from every constituency and region of Scotland. The guests included 'local heroes' nominated by their respective MSPs on account of community and charitable work. Also dispersed in the 'riding', in echoes of the 1999 procession, were sixteen colourful banners from the eight regions of Scotland. When the procession reached the Parliament building all participants entered to either watch the internal formalities in the public gallery or on television screens located throughout the complex. Therefore, while this was (other than a few police horses) no equestrian event as in 1703 or 1999, as a processional journey before the populace and prior to the internal rituals of the house, it retained some of the qualities of the traditional 'riding'. Importantly, following 1999 and the precedents of the pro-Union Parliament, at the rear of the 'riding' the duke of Hamilton carried out his duties as bearer of the crown and, under military escort, accompanied it from Old Parliament Hall, to the new Parliament chamber. ${ }^{36}$

2007 not only saw a seismic shift in political terms, with the Labour Party losing the election, but also to a degree in how ceremonial was employed at the state opening that June. ${ }^{37}$ On a day when the press coverage swung to an attack on Glasgow Airport by Muslim fundamentalists, ${ }^{38}$ the external ceremonial was altered significantly from traditional norms and from the procedure of 1999 and 2004. While the spatial geography of palace and parliament remained as in 2004, the relationship with the people changed. What occurred was a three stage process: opening ceremony, 'riding' procession and free public concert. To start stage one, the Queen only travelled the short journey by car from the Holyrood Palace to Queensberry House just next door to the Parliament. A modest crowd of onlookers were present to view this short journey. Meanwhile, the duke of Hamilton accompanied the transporting of the crown from Edinburgh Castle, travelling by car under military escort at precisely $9.55 \mathrm{am}$. The BBC broadcast on the day began at 10.00 am with a recorded image of the crown being collected and commencing its traditional journey. The crown did not, however, take up the conventional position at the rear of a 'riding' of members of parliament but as an isolated ceremonial progress. At 10.45 the Queen entered the chamber with the crown and accompanying honour guard of the Royal Company of Archers and persuvants and heralds and, after a mere 15 minutes, they left the chamber. Thereafter, the Queen occupied a dais at the foot of the Royal Mile to witness a new type of 'riding', the second stage of the festivities. ${ }^{39}$

\footnotetext{
${ }^{35}$ BBC (Scotland) live television broadcast, 9 October, 2004; Scottish Parliament Annual Report at http://www.scottish.parliament.uk/corporate/anrep-accts/spar/ar-05/ceremony.htm

${ }^{36}$ It had already been transported from Edinburgh Castle to the Old Parliament Hall earlier in the day.

${ }^{37} \mathrm{BBC}$ (Scotland) live television broadcast, 30 June, 2007 and also at the Scottish Parliament website at http://www.holyrood.tv/library.asp?title=Session\%203\%20Event\%20Archive\&section=99 ;

${ }^{38}$ Sunday Herald, 30 June, 2007 (report by Torcuil Crichton)

${ }^{39}$ Scottish Parliament News Release 067/2007, 29 June, 2007
} 
In essence this new 'riding' was as much a party as the celebration of 2004, with costume and jugglers as well as invited 'local heroes': it was a parade of people and performers rather than a procession with strong resonances of past tradition or, it could be argued, of shared sovereignty. The Royal Marines Band led a diverse procession consisting of 1,200 people: dancing companies, groups of school children with banners (as in 1999), an Indian street band, youth theatre, MSPs and their guests and 'local heroes', lord provosts from around Scotland, sports stars and members of the consular corp of various nations, and concluding with a large pipe band. ${ }^{40}$ Matters of youth, musicality, internationalism and community were evoked in procession as the throng made its 30 minute movement from Market Street to the Royal Mile, through the Canongate, ending at the Parliament's landscaped gardens at the foot of the Royal Mile. Once the 'riding' was completed a free public music event took place under the label 'picnic-in-the-parliament' in the grounds of Holyrood. And so how are we then to judge this type of procession? As one that informs the people that Parliament is meeting; that the crown is borne to it representing the traditional acknowledgment of sovereignty shared by people, representatives and monarch, and that the members themselves present themselves publicly, it satisfied the traditional objectives of the opening ceremony and 'riding'. However, this 'riding' took place after the opening formalities in the chamber. This removes, inadvertently perhaps, an element of that signification of approval that Parliament has gathered as a representative assembly.

The opening ceremony of 1999 was indeed a compromise but one that respected the tradition of the old pre-1707 Parliament. Also, inevitably, new concerns since the Union influenced the event and so with the devolution of some sovereignty came a degree of devolution of British ritual, and the new Parliament was infused with Westminster processes as royal assent is signed for and a mace provided to confirm the link between the Scottish Parliament and a British crown. Nonetheless, in 1999 especially, the essence of the 'riding' of parliament lived on: in the procession from palace to parliament before the rituals in the chamber; the use of the honours of Scotland and the relative informality of the relationship between chamber and monarch. In 2003 ritual was suspended out of political expediency. However, in 2004 when the Parliament moved into its new home at Holyrood, the external spatial geography of ritual altered. The close proximity of palace and parliament now meant the riding had to be manufactured. Now the Queen moved up and down the Royal Mile by car not coach, first to the Old Parliament house to hear speeches; then to sit at a raised platform to watch parliamentarians and community groups march down the street to the new building, before being driven down herself. In 2004 and 2007 only the crown of Scotland completed a traditional journey from the fortified castle to the free representative chamber. No horses are used at all. The 'riding', and even more so in 2007, is now more carnival than state procession and occurs after the internal formalities. But meanwhile internally the chamber retains much more of the solemnities of old in a very brief ceremony without the music and cultural registers of 1999 and 2004. The opening of the first parliament to meet for 300 years and the opening of the first new parliamentary building since the 1630s can now be seen as grand social and cultural celebrations but also parts of a process to establish new traditions of ritual.

\footnotetext{
${ }^{40}$ For participants see http://www.scottish.parliament.uk/nmCentre/news/session3/riding_participants.pdf
} 
Nonetheless there are many obvious changes in 1999 and 2007 compared to 1703: the appearance of women as members of parliament, and within processions, the police and the army; the replacement of estates by political party and members of equal status which altered the 'architecture' of the chamber and procession, and lastly the involvement of children and constituency 'heroes' from local communities representing a universal electorate. Nevertheless, the denoting of parliamentary sovereignty was as essential in 2007 as pre-1707: as rendered before monarch, honours of state and elected representatives. As the late First Minister Donald Dewar put it in his speech before parliament on 1 July 1999, the opening of a new parliament was 'a rare privilege in an old country' and represented 'a modern ceremony in a traditional context'. ${ }^{11}$ And yet since 1999 the architectural geography of Scotland's capital has produced different versions of parliamentary ritualism and it is not clear, even in 2007, that a new tradition has been forged.

\footnotetext{
${ }^{41}$ BBC (Scotland) live broadcast, 1 July 1999; http://www.scottish.parliament.uk/vli/history/donaldDewar/
} 